\title{
Kombinasi Balanced Scorecard dan Objective Matrix Untuk Penilaian Kinerja Perguruan Tinggi
}

\author{
A. Aviv Mahmudi ${ }^{* a}$, Bayu Surarso ${ }^{\mathrm{b}}$, Agus Subagio ${ }^{\mathrm{c}}$ \\ ${ }^{a}$ STIE YPPI Rembang, Jawa Tengah \\ ${ }^{b}$ Jurusan Matematika, Fakultas Sains dan Matematika, Universitas Diponegoro \\ ${ }^{c}$ Jurusan Fisika, Fakultas Sains dan Matematika, Universitas Diponegoro
}

Naskah Diterima : 10 Februari 2014; Diterima Publikasi : 10 Maret 2014

\begin{abstract}
Working Assessment is very essential aspect for a college to keep its excellent quality to face tight competition in either national or international level. The working assessment can be implemented to compare the result with organization strategy, and can also help to plan the upcoming strategy to achieve the final target of organization. The combination of Balanced Scorecard and OMAX is aimed at building the information system of working assessment in a college. Balanced Scorecard in the college is used to determine the strategic purposes, KPI and target, optimistic and pessimistic value. The scoring of each KPI uses AHP method; the scoring of KPI influences on general working score. The scoring of working assessment uses Objective Matrix (OMAX) method to know the total result indicator stated by the college, and can find out the total result indicator of each working criterion. The combination of BSC and OMAX can avoid the use of overwhelming data because this model focused on four perspectives, with the important key indicator of a college. Besides, the four perspectives can avoid the orientation of short-term target, because OMAX developed the more obvious frame of time that also focused on the long-term target. This combination was a good integration that can afford to modify hybrid model in determining the score card of a college. BSC changed into the form of OMAX that presented a target in the long period. This combination is also a good integration that can afford to modify a hybrid model in determining the scorecard of the college. BSC changes into the form of OMAX that presents the long-term target.
\end{abstract}

Keywords: AHP; Balanced scorecard; OMAX; Work assessment; College

\begin{abstract}
Abstrak
Penilaian kinerja merupakan hal yang esensial bagi perguruan tinggi untuk tetap unggul dalam menghadapi persaingan di kancah nasional maupun global. Dengan penilaian kinerja dapat digunakan untuk membandingkan antara hasil dengan strategi organisasi, serta dapat membantu merencanakan strategi masa depan untuk mencapai target akhir organisasi. Kombinasi Balanced Scorecard, OMAX bertujuan untuk membangun system iformasi penilaian kinerja perguruan tinggi. Balanced Scorecard pada perguruan tinggi digunakan untuk menentukan tujuan strategis, KPI serta target, nilai optimis dan pesimis. Pembobotan dari masing-masing KPI menggunakan metode AHP, bobot dan skor KPI berpengaruh pada skor kinerja secara keseluruhan. Skoring penilaian kinerja menggunakan metode Objective Matrix (OMAX) untuk mengetahui indicator capaian dari target yang telah ditetapkan perguruan tinggi, serta dapat melihat indicator pencapaian total masingmasing criteria kinerja. Kombinasi BSC dan OMAX dapat menghindari penggunaan terlalu banyak data karena model ini berfokus pada empat perspektif, dengan indicator kunci (KPI) penting pada perguruan tinggi. Selain itu dari 4 perspektif yang ada dapat menghindari orientasi sasaran jangka pendek, karena OMAX mengembangkan kerangka waktu yang lebih jelas yang juga berfokus pada ukuran jangka panjang. Kombinasi ini merupakan integrasi yang baik yaitu mampu memodifikasi dalam model hybrid pada penentuan scorecard perguruan tinggi.BSC berubah menjadi bentuk OMAX yang menyajikan sasaran dalam jangka panjang.
\end{abstract}

Kata kunci: AHP; Balanced scorecard; OMAX; Penilaian kinerja; Perguruan tinggi

\section{Pendahuluan}

Konsep Balanced Scorecard (BSC)merupakan sebuah model sistem pengukuran kinerja yang menyediakan kerangka komprehensif serta menjadi sebuah solusi yang baik dalam kerangkapengukuran kinerja (Lee et al., 2008). Pengukuran pada indikator keuangan serta indikator kualitatif lainnya sangat

*) Penulis korespondensi: viva_77@yahoo.co.id dibutuhkan dalam mencapai keseimbangan pengukuran kinerja (Aljardali et al., 2012).

BSC menghubungkan entitas, visi, misi, strategi masa depan, nilai-nilai inti, dan target, yang dirancang untuk memotivasi organisasi ke arah perbaikan secara terus menerus serta menghasilkan pengambilan keputusan yang efektif dan efisien (Beard, 2009). 
Dalam penerapannya, Balanced Scorecard dapat dimanfaatkan sebagai alat perencanaan strategis, sistem pelaporan strategis, untuk memenuhi permintaan dan akuntabilitas, serta peningkatan layanan perguruan tinggi (Sordo et al., 2012).

Untuk mendukung Balanced Scorecard sebagai metode penilaian kinerja, dapat dikombinasikan dengan metode Analytical Hierarchy Process (AHP) untuk pembobotan dari masing-masing Key Performance Indicator (KPI) (Bentes et al., 2011).AHP merupakan model pendukung keputusan yang menguraikan masalah multi faktor atau multi kriteria yang kompleks menjadi suatu hierarki (Lee, 2010).

Untuk menyusun pedoman pengukuran kinerja dalam bentuk skor secara keseluruhan pada setiap indikator performa, dibutuhkan suatu normalisasi dari ukuran kinerja yang berbeda ke dalam suatu nilai indeks atau skor yang dinormalisasi menjadi skor tunggal (Sulisworo,D., dan Darmawati, D., 2011). Dengan skor tunggal tersebut memungkinkan manajemen untuk mengidentifikasi apakah kinerja telah meningkat dari waktu ke waktu (Torodovic, 2011). Objective Matrix (OMAX) merupakan metode yang digunakan dalam menormalisasi, mengkonversikan nilai setiap ukuran kinerja menjadi indeks kinerja (Purnomo, 2011).

Kombinasi Balanced Scorecard, AHP, danOMAXdalam penilaian kinerja perguruan tinggi denganstudikasus di STIE YPPI Rembangdiharapkan dapat mengetahui tingkat kinerja dari masing-masing Key Performance Indicator (KPI) serta dapat dijadikan rujukan pihak manajemen dalam melakukan perbaikan kinerja pada masing-masing indikator performa. Adapun pembobotan dari tiaptiap perspektif dan KPI menggunakan metode AHP, sedangkan OMAX digunakan sebagai sistem skoring untuk mengetahui indikator capaian dari target yang telah ditetapkan perguruan tinggi, serta dapat melihat indikator pencapaian total masing-masing kriteria kinerja.

\section{Kerangka Teori}

\subsection{Balanced Scorecard (BSC)}

Balanced Scorecard (BSC) merupakan suatu konsep pengukuran kinerja yang mengakomodasi berbagai indikator kinerja ke dalam suatu konsep yang menghubungkan visi, misi, dan strategi masa depan, target, dan inisiatifyang secara eksplisitdirancang untuk menginformasikan, memotivasi, kemudian diukur dan dimonitor secara berkelanjutan (Beard, 2009). Konsep ini memperkenalkan suatu sistem pengukuran kinerja dengan menggunakan kriteria-kriteria tertentu dari perspektif pelanggan, keuangan, bisnis internal serta pembelajaran dan pertumbuhan (Wu et al., 2011)

\subsection{Analytical Hierarchy Process (AHP)}

Analytical Hierarchy Process (AHP) merupakan metode pengambilan keputusan yang dikembangkan oleh Prof. Thomas. L. Saaty dari University of Pittsburgh pada tahun 1970-an. Di dalam penerapan AHP, keputusan diambil dengan cara membandingkan secara berpasangan alternatifalternatif yang akan dipilih dengan menggunakan kuisioner perbandingan berpasangan dimana di dalam penilaian bobot kepentingannya melibatkan para responden ahli yang mengerti dan memahami tujuan dan sasaran institusi (Pedrycz, 2014).

Langkah-langkah dalam metode AHP meliputi menyusun hierarki dari permasalahan yang dihadapi. Penilaian kriteria dan alternatif dinilai melalui perbandingan berpasangan.Tabel 2.1 menunjukkan skala perbandingan berpasangan, untuk berbagai persoalan skala 1 sampai 9 adalah skala terbaik dalam mengekspresikan pendapat.

Tabel 1. Skala perbandingan berpasangan

\begin{tabular}{cl}
\hline $\begin{array}{c}\text { Intensitas } \\
\text { Kepentingan }\end{array}$ & \multicolumn{1}{c}{ Keterangan } \\
\hline 1 & $\begin{array}{l}\text { Kedua elemen sama pentingnya } \\
\text { Elemen yang satu sedikit lebih penting } \\
\text { daripada elemen yang lainnya }\end{array}$ \\
5 & $\begin{array}{l}\text { Elemen yang satu lebih penting daripada } \\
\text { yang lainnya }\end{array}$ \\
7 & $\begin{array}{l}\text { Satu elemen jelas lebih mutlak penting } \\
\text { daripada elemen lainnya }\end{array}$ \\
9 & $\begin{array}{l}\text { Satu elemen mutlak penting daripada } \\
\text { elemen lainnya }\end{array}$ \\
$2,4,6,8$ & $\begin{array}{l}\text { Nilai-nilai antara dua nilai pertimbangan- } \\
\text { pertimbangan yang berdekatan }\end{array}$ \\
Resiprokal, & $\begin{array}{l}\text { Jika elemen } i \text { memiliki salah satu angka } \\
\text { diatas ketika dibandingkan elemen j, } \\
\text { jika A/B=9 } / \text { maka jemiliki kebalikannya ketika } \\
\text { maka }\end{array}$ \\
B/A=1/9 & $\begin{array}{l}\text { disbanding elemen i } \\
\text { Sumber Saty }\end{array}$
\end{tabular}

Sumber: Saaty (1990)

1. Penentuan Prioritas

Untuk setiap kriteria dan alternatif perlu dilakukan perbandingan berpasangan (pairwise comparisons) seperti pada Gambar 1, dimana jika $a_{i j}=1$ dan $=\quad=-, \mathrm{i}, \mathrm{j}=1,2 \ldots \mathrm{n}$. Nilai-nilai perbandingan relatif kemudian diolah untuk menentukan peringkat alternatif dari seluruh alternatif.

2. Konsistensi Logis

Dalam pembuatan keputusan, penting untuk mengetahui seberapa baik konsistensi yang ada,langkahnyaadalah :

a. Mengalikansetiapnilaipadakolompertamadengane lemenprioritaspertama,

nilaipadakolomkeduadenganelemenprioritaskedua , danseterusnya.

b. Kemudianmenjumlahkansetiapbaris 
c. Hasil penjumlahan tiap baris dibagi prioritas bersangkutan danhasilnya dijumlahkan (vector konsistensi)

d. Hasil c dibagi dengan banyaknya elemen yang ada, hasilnyadisebut $\lambda$

$$
\lambda=\frac{\sum}{\sum}(1)
$$

Keterangan :

$$
\begin{aligned}
& \lambda \quad=\text { Nilai rata-rata vector consistency } \\
& \begin{array}{ll}
\lambda V & =\text { Vektor Konsistensi } \\
n & =\text { Jumlah faktor yang sedang }
\end{array} \\
& \text { dibandingkan }
\end{aligned}
$$

e. Menghitung consistency index (CI) dengan rumus

$$
=\underline{\lambda}
$$

f. Menghitung rasio konsistensi/consistency ratio (CR) dengan rumus :

$$
=-
$$

Memeriksa konsistensi hierarki, nilai konsistensi rasio harus kurang dari 5\% untuk matriks $3 \times 3,9$ $\%$ untuk matriks $4 \times 4$ dan $10 \%$ untuk matriks yang lebih besar (Lee et al., 2008). Jika lebih dari rasio dari batas tersebut maka nilai perbandingan matriks diulang kembali.PadaTabel2.2 menampilkandaftarindeks random konsitensi yang digunakansebagai penentuan nilai IR sesuaidenganukuranmatriksmasing-masing $\quad(\mathrm{Wu}$ et al., 2012).

Tabel 2. Daftar indeks random konsistensi

$\begin{array}{llllllllll}\text { Ukuran } & 2 & 3 & 4 & 5 & 6 & 7 & 8 & 9 & 10\end{array}$

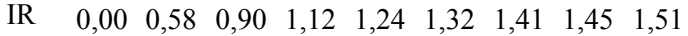

Sumber: Saaty (1990)

Selanjutnya dari hasil analisis preferensi gabungan dari responden, kemudian dihitung nilaigeomeannya (geometrik), yaitu nilai sentral yang dianggap mewakili nilai seluruh data yangdiperoleh dari nilai kualifikasi persepsi dikalikan satu dengan lainnya dan dicaripangkat dari jumlah responden(Elgazzar, 2012).

$$
=\sqrt{ } \cdot \ldots
$$

Dari hasil tersebut selanjutnya membentuk matrix pair-wise comparasion yang membandingkan antara masing-masing perspektif dan KPI.

\subsection{Objective Matrix (OMAX)}

Model pengukuran produktivitas OMAX mengatasi masalah-masalah kerumitan dan kesulitan pengukuran produktivitas dengan mengkombinasikan seluruh kriteria produktivitas yang penting dalam suatu bentuk matrix yang terpadu dan saling terkait (Jaaskelainen, 2009).

Langkah pertama adalah pendefinisian (Defining), pada bagian atas matriks terdapat kriteria produktivitas berupa perbandingan yang merupakan nilai kerja produktif dari suatu unit kerja serta berpengaruh pada tingkat produktivitas. Berikutnyapengukuran (Quantifying), pada badan matriks ditunjukkan tingkat pencapaian unjuk kerja untuk kriteria produktivitas. Tingkatan tersebut dibagi dalam 10 tingkat. Nilai-nilai menunjukkan tingkat dimana matriks pengukuran dimulai. Jika nilai kurang dari hasil minimum yang dapat diterima, maka nilai dianggap nol (0). Penentuan skala kinerja antara skala 0, skala 3 dan skala 10 (Jaaskelainen, 2009).

a. Skala 0 : menunjukkan pencapaian kinerja terendah (paling tidak memuaskan).

b. Skala 3 : menunjukkan rata-rata pencapaian kinerja pada saat pengukuran kinerja ini dirancang (target).

c. Skala 10 : menunjukkan target pencapaian kinerja yang ingin dicapai pada masa mendatang (nilai maksimal yang mungkin diperoleh).

Kenaikan nilai produktivitas yang disesuaikan dengan interpolasi, dimana skor 1 dan 2 diperoleh dari interpolasi nilai pada skor 0 dan 3. Hasil interpolasi tersebut dijadikan interval skor 0 sampai skor 3. Skor 4-9 didapat dari interpolasi nilai pada skor 3 dan 10. Hasil interpolasi tersebut dijadikan sebagai interval antara skor 3 sampai skor 10 (Faridz, 2011). Perhitungan interval kelas menggunakan rumus :

$$
\Delta \quad=
$$

Pengisian skala skor yang tersisa lainnya dari matriks dilakukan langsung setelah butir skala nol, tiga, sepuluh telah terisi. Adapun butir yang tersisa diisi dengan jarak antar skor adalah sama, dengan menggunakan rumus sebagai berikut (Dania, 2012):

$$
\begin{aligned}
& \text { Nilai Level }= \\
& \text { Nilai Level }(X+1)-\text { Interval Kelas }
\end{aligned}
$$

Monitoring merupakan hasil perbandingan dari operasi yang berlangsung ditempatkan di bagian atas matriks, kemudian disesuaikan dengan tingkatan pada badan matriks, dan dicatat dalam baris nilai tingkatan (score). Angka pada baris bobot (weight), menunjukkan derajat kepentingan dari masingmasing kriteria, yang kemudian dikalikan dengan nilai atasnya (score), lalu dicatat dalam baris nilai (value). Hasil penjumlahan dari value merupakan nilai performance dari periode yang diukur.

Value $=$ Level (score) $x$ Bobot (weight)

Perhitungan Skor Kinerja Total, skor kinerja total merupakan langkah terakhir. Perhitungannya dengan menjumlahkan seluruh skor ukuran kinerja.

\section{Metodologi}

Bahan penelitian yang digunakan dalam proses penelitian ini diperoleh antara lainmelalui survey 
dengan mengisi kuisioner onlineoleh mahasiswa dan karyawan. Selain itu juga data-data yang diperoleh dari laporan tahunan ketua, dokumen, file, arsip dari perguruan tinggi.

Untuk data bobot yang digunakan untuk penilaian kinerja perguruan tinggi diperoleh dari pegisian kuisioner online menggunakan metode AHP, kuisioner bobot kepentingan diisi oleh pimpinan perguruan tinggi (pejabat pembuat keputusan).

\subsection{Prosedur Penelitian}

Dalam mengimplementasikan Balanced Scorecard untuk mengukur kinerja, ada kerangka kerja yang terdiri dari 4 tahapan yang harus dilakukan untuk menghasilkan sebuah scorecard sebagai alat ukur kinerja yaitu : Strategic Alignment, Strategic Areas, Strategy Grid, dan Company Scorecard.

1. Strategic Alignment

Berdasarkan visi, misi, dan strategi perguruan tinggi, kemudian dirumuskan strategic goal yaitu strategi-strategi yang harus dilaksanakan dan targettarget yang harus dicapai oleh perguruan tinggi. Target yang disusun harus memiliki parameter pengukuran yang jelas. Pada STIE YPPI didapatkan 23 strategic goal yang didapatkan dengan menjabarkan 13 kebijakan.

2. Strategic Areas

Pada STIE YPPI, didapatkan 13strategic areas yang merupakan generalisasi daribeberapa strategi yang didapat pada tahap strategy alignment.

3. Strategy Grid

Setelah didapatkan strategic areas, langkah selanjutnya adalah melakukan strategy grid, yaitu mengidentifikasi indikator yang sudah ada sehingga didapat hubungan sebab-akibat yang mengacu pada terwujudnya visi dan misi perguruan tinggi. Hasil dari strategy grid ini berupa berupa strategy map.

\section{Company scorecard}

Membangun company scorecard yang didapat dengan memetakan hubungan perspektif balanced scorecard, strategic areas, strategy grid, dengan visi, misi dan strategi perguruan tinggi. Company scorecard dipetakan kedalam indikator kinerja dari masing-masing perspektif.

Pada implementasi perangkat lunak pada sistem informasi penilaian kinerja menggunakan kombinasi BSC dan OMAX, Flowchart perangkat lunakditunjukkan pada gambar 1

Setelah menentukan KPI, tujuan strategis, serta target dari masing-masing KPI, dilakukan penentuan bobot dari masing-masing KPI dengan menggunakan penyebaran kuisioner AHP pada 6 pimpinan perguruan tinggi yaitu Ketua, Pembantu Ketua I, II, danIII, serta Ketua Program Studi Manajemen-S1, dan Akuntansi-S1.

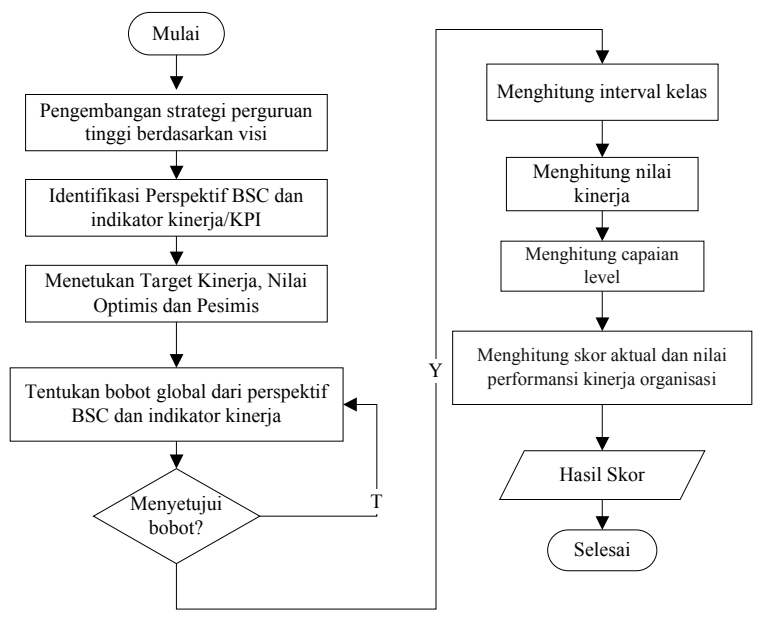

Gambar 1. Flowchart perangkat lunak kombinasi BSC dan OMAX

Pembobotan KPI perlu dilakukan agar fungsifungsi kinerja organisasi yang diukur menggunakan KPI bisa berjalan dengan baik. Pembobotan KPI dilakukan dengan melihat tingkat kepentingan kinerja organisasi yang diukur melalui KPI. KPI yang memiliki tingkat kepentingan tinggi pada kinerja organisasi mendapatkan prioritas yang lebih.

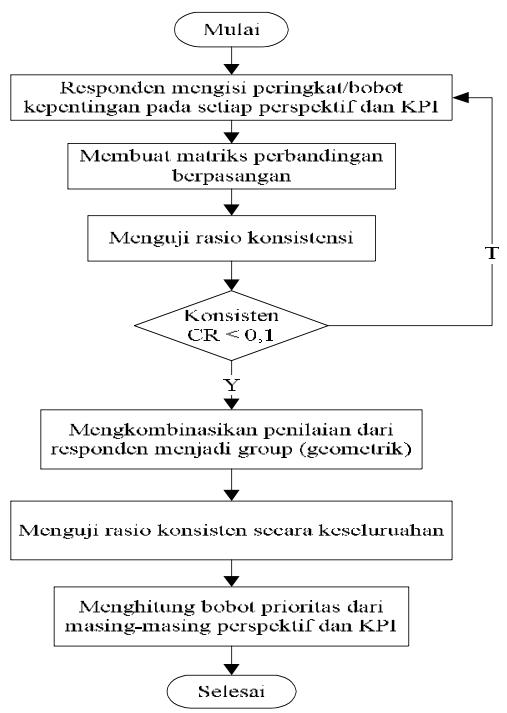

Gambar 2. Flowchart perangkat lunak pembobotan dengan AHP

Tahap selanjutnya adalah memadukan model pengukuran kinerja dengan menggunakan model scoring system yaitu model OMAX (Objective Matrix) sehingga didapatkan pencapaian tiap-tiap parameter dari KPI yang ada serta dapat diketahui kinerja perguruan tinggi secara keseluruhan. 


\subsection{Analisis Data}

Pada tahap ini meliputi langkah penyusunan pengukuran BSC, pembobotan, serta scoring penilaian kinerja perguruan tinggi. Tahapan analisa dan pengolahan data dimulai dari mengidentifikasi KPI dari Balanced Scorecard, selanjutnya menyusun ukuran kinerja sehingga diperoleh skor aktual dan nilai performasi dari masing-masing perspektif dan KPI, sebagaimana terlihat pada Gambar 3.3.

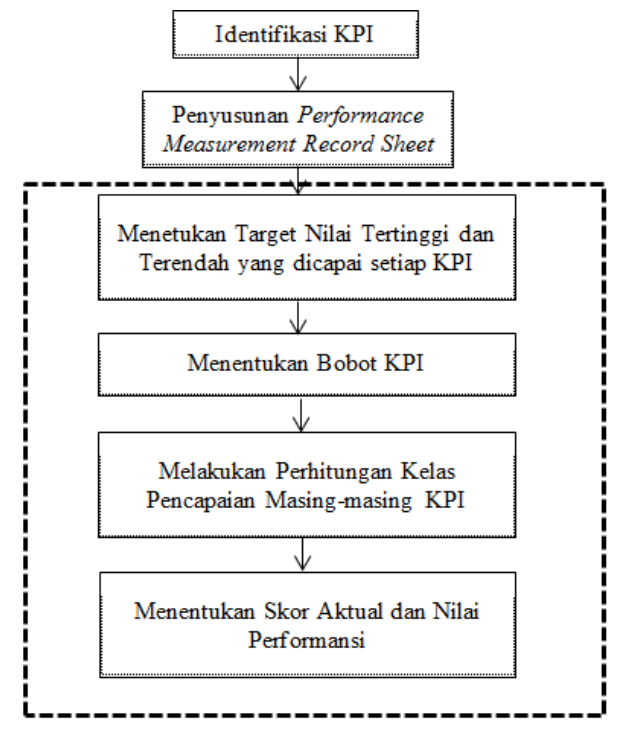

Gambar 3. Blok diagram analisa dan pengolahan data

\section{Hasil dan Pembahasan}

Pada penelitian ini dihasilkan penilaian kinerja perguruan tinggi menggunakan kombinasi Balanced Scorecard dan OMAX yang bertujuan untuk membangun system informasi kinerja perguruan tinggi. Sistem informasi tersebut menyajikan capaian kinerja ditinjau dari 4 perspektif: pelanggan, keuangan, bisnis internal, pembelajaran dan pertumbuhan. Masing-masing perspektif memiliki key performance indicator (KPI) sebagai tolok ukur kinerja perguruan tinggi dengan studi kasus pada STIE YPPI Rembang.

Pembobotan dengan metode AHP didasarkan hasil kuisioner dari 6 narasumber yang berkompeten pada STIE 'YPPI' Rembang diantaranya Ketua, Pembantu Ketua 1, 2, dan 3, Ketua Program StudiManajemen, dan Akuntansi. Pembobotan antar perspektif dan masing-masing KPI menggunakan metode AHP. Dengan melibatkan unsur pimpinan perguruan tinggi, dapat mengurangi unsur subjektifitas dalam memberikan bobot dari masingmasing indikator kinerja. Hal ini dapat dibuktikan dengan data pembobotan dari masing-masing responden pada perhitungan bobot yang telah dilakukan sebelumnya.

Pengisian kuisioner perbandingan berpasangan dilakukan secara online, dengan mengisi tingkat kepentingan dari masing-masing ukuran kinerja,tiap perspektif dengan membandingkan ukuran kinerja yang satu dengan yang lain. Pembobotan global untuk masing-masing perspektif dengan menghitung nilai geometrik. Tabel 3 merupakan perhitungan ratarata untuk pembobotan global untuk matriks perbandingan berpasangan antara perspektif pelanggan.

Tabel 3. Geometrik dari perspektif pelanggan

\begin{tabular}{lcccc}
\hline Perspektif & $\begin{array}{c}\text { Pelanggan } \\
\text { (P 1) }\end{array}$ & $\begin{array}{c}\text { Keuangan } \\
\text { (P 2) }\end{array}$ & $\begin{array}{c}\text { Bisnis } \\
\text { Internal } \\
\text { (P 3) }\end{array}$ & $\begin{array}{c}\text { Pembelajaran } \\
\text { dan } \\
\text { Pertumbuhan } \\
\text { (P 4) }\end{array}$ \\
\hline $\begin{array}{l}\text { Pelanggan } \\
\text { (P 1) }\end{array}$ & 1,00 & 2,31 & 1,57 & 2,57 \\
$\begin{array}{l}\text { Keuangan (P 2) } \\
\text { Bisnis }\end{array}$ & 0,43 & 1,00 & 0,69 & 0,64 \\
$\begin{array}{l}\text { Internal } \\
\text { (P 3) }\end{array}$ & 0,64 & 1,44 & 1,00 & 2,35 \\
$\begin{array}{l}\text { Pembelajaran } \\
\text { dan }\end{array}$ & 0,39 & 1,56 & 0,43 & 1,00 \\
$\begin{array}{l}\text { Pertumbuhan } \\
\text { (P 4) }\end{array}$ & & & & \\
\hline \multicolumn{1}{c}{ Jumlah } & 2,46 & 6,31 & 3,69 & 6,56 \\
\hline
\end{tabular}

Dari hasil tersebut selanjutnya membentuk matrix pair-wise comparasion yang membandingkan antara masing-masing perspektif dan KPI, serta memproses sesuai dengan langkah-langkah AHP untuk mencari bobot serta memeriksa konsistensi. Langkah yang sama dilakukan pada semua perspektif.

Tabel 4. Rekapitulasi bobot dan nilai CR perspektif BSC dan KPI

\begin{tabular}{|c|c|c|c|c|c|}
\hline $\begin{array}{c}\text { Kode } \\
\text { Perspektif }\end{array}$ & $\begin{array}{c}\text { Bobot } \\
\text { Perspektif }\end{array}$ & $\begin{array}{c}\text { Nilai } \\
\mathrm{CR}\end{array}$ & $\begin{array}{l}\text { Kode } \\
\text { KPI }\end{array}$ & Bobot KPI & Nilai CR \\
\hline \multirow{8}{*}{ P 1} & \multirow{7}{*}{0,3974} & & C 1 & 0,329 & \multirow{8}{*}{0,0223} \\
\hline & & & C 2 & 0,172 & \\
\hline & & & C 3 & 0,209 & \\
\hline & & & $\mathrm{C} 4$ & 0,052 & \\
\hline & & & C 5 & 0,117 & \\
\hline & & & C 6 & 0,080 & \\
\hline & & & C 7 & 0,040 & \\
\hline & \multirow{5}{*}{0,1551} & & F 1 & 0,191 & \\
\hline \multirow{4}{*}{ P 2} & & & F 2 & 0,163 & \multirow{3}{*}{0,0021} \\
\hline & & & F 3 & 0,271 & \\
\hline & & & F 4 & 0,375 & \\
\hline & & 0,001 & BI 1 & 0,287 & \multirow{5}{*}{0,018} \\
\hline \multirow{4}{*}{ P 3} & \multirow{4}{*}{0,2792} & & BI 2 & 0,450 & \\
\hline & & & BI 3 & 0,121 & \\
\hline & & & BI 4 & 0,055 & \\
\hline & & & BI 5 & 0,086 & \\
\hline \multirow{7}{*}{ P 4} & & & LG 1 & 0,274 & \multirow{7}{*}{0,0299} \\
\hline & & & LG 2 & 0,229 & \\
\hline & & & LG 3 & 0,196 & \\
\hline & 0,1683 & & LG 4 & 0,079 & \\
\hline & & & LG 5 & 0,104 & \\
\hline & & & LG 6 & 0,069 & \\
\hline & & & LG 7 & 0,049 & \\
\hline
\end{tabular}


Dari hasil rekapitulasi bobot global untuk masingmasing perspektif diperoleh hasil, perspektif pelanggan ( $\mathrm{P}$ 1) memiliki bobot global paling tinggi sebesar 39,74\%. Selanjutnya perspektif bisnis internal (P 3) memiliki bobot global 27,92\%, perspektif pembelajaran dan pertumbuhan ( $\mathrm{P} 4$ ) dengan bobot $16,83 \%$. sedangkat bobot global paling rendah menurut unsur pimpinan perguruan tinggi adalah perspektif keuangan (P 2) sebesar 15,51\%, sehingga mencapai bobot total $100 \%$.

Pendekatan Balanced Scorecard yang menekankan hubungan strategi dengan ukuran kinerja, hanya menampilkan rincian kinerja dalam bentuk metrik yang ditempatkan di kotak scorecard. Untuk mengurangi kelemahan dari BSC ini, peneliti mengintegrasikan konsep BSC dan metode OMAX. Pada penelitian ini menghasilkan pengembangan/modifikasi template yang sesuai dengan kondisi perguruan tinggi, dengan area fungsional yang berbeda, sehingga memerlukan langkah-langkah dan tingkat yang berbeda dari target kinerja. Perbedaan tersebut adalah penentuan capaian nilai maksimal (nilai optimis)/ sasaran jangka panjang serta nilai optimis yaitu nilai terendah yang mengkin dicapai perguruan tinggi selain penentuan target kinerja. Modifikasi tersebut dalam model hybrid, dimana pada penentuan scorecard (kartu skor) perguruan tinggi pada 4 perspektif BSC berubah menjadi bentuk OMAX.

Kombinasi Balanced Scorecard (BSC) dan OMAX mampu memberikan kontribusi lebih sehingga dapat memaksimalkan penelitian ini. Peran ketiganya yang diintegrasikan dalam Sistem Informasi Penilaian Kinerja perguruan tinggi telah mencapai tujuan yang diinginkan, sehingga memberikan manfaat bagi perguruan tinggi dalam melakukan penilaian kinerja. Kombinasi BSC dan OMAX memiliki skor indikator kinerja yang jelas dan fleksibel, sehingga setiap sasaran kinerja dapat dipantau dan dikendalikan dengan perspektif Balanced Scorecard.

Kombinasi BSC dan OMAX pada pengukuran kinerja memberikan informasi yang baik dan valid yang diperlukan pihak manajemen sebagai pendukung keputusan untuk perbaikan organisasi dalam hal ini perguruan tinggi. Pendekatan ini memungkinkan untuk digunakan pada perencanaan dan pengukuran kinerja, sehingga dapat menjaga efektivitas, efisiensi, kualitas, waktu, dan produktivitas. Selain itu, keuntungan dari manajemen kinerja organisasi adalah pendekatan terstruktur yang berfokus pada perencanaan strategis, tujuan, dan kinerja, serta untuk menyediakan mekanisme pelaporan program kinerja manajemen yang lebih tinggi.

Kombinasi BSC dan OMAX dapat menghindari penggunaan terlalu banyak data karena model ini berfokus pada 4 perspektif, dengan indikator kunci (KPI) penting pada perguruan tinggi. Penilaian kinerja dengan data yang jelas dapat mendukung keputusan yang baik dalam menentukan strategi masa depan. Selain itu juga dapat menghindari orientasi sasaran jangka pendek, karena OMAX mengembangkan kerangka waktu lebih jelas, yang juga berfokus pada ukuran jangka panjang. Kombinasi ini merupakan integrasi yang baik yaitu mampu memodifikasi dalam model hybrid pada penentuan scorecard perguruan tinggi untuk BSC yang berubah menjadi bentuk OMAX yang menyajikan sasaran dalam jangka panjang.

Pada model skoring sistem dengan OMAX, dilakukan dengan menyusun format pedoman pengukuran kinerja, diantaranya performance yaitu hasil kinerja yang telah dicapai. Level 0 s.d 10 merupakan nilai skala kinerja dari suatu ukuran kinerja merupakan nilai parameter terbesar yang sama dengan atau kurang dari nilai ukuran kinerja.

Dalam mengisi level pada nilai kinerja diawali dengan menentukan nilai optimis yang merupakan peningkatan nilai target yang ingin dicapai, dimasukkan pada level 10. Kemudian menentukan juga nilai pesimis yaitu nilai terendah yang mungkin dicapai perguruan tinggi pada suatu periode, dimasukkan pada level 0 . Sedangkan target dimasukkan pada level 3.

Untuk pengisian leveldigunakan rumus interpolasi. Untuk weightdiisi dengan nilai bobot KPI, adapun rekapitulasi interval dari semua KPI pada perspektif pelanggan sebagaimana Tabel 5, sedangkan interval dari semua KPI yang lain mengikuti cara yang sama.

Tabel 5. Rekapitulasi interval perspektif pelanggan

\begin{tabular}{cccccccc}
\hline Interval & \multicolumn{8}{c}{ Key Performance Indicator (KPI) } \\
Kelas & C 1 & C 2 & C 3 & C 4 & C 5 & C 6 & C 7 \\
\hline $10-3$ & 0,057 & 0,086 & 0,714 & 0,714 & 2,143 & 1,429 & 0,714 \\
$3-0$ & 0,300 & 0,200 & 1,667 & 1,667 & 5,000 & 5,000 & 5,000 \\
\hline
\end{tabular}

Tabel 6. Skoring perspektif pelanggan

\begin{tabular}{|c|c|c|c|c|c|c|c|c|}
\hline \multirow{2}{*}{\multicolumn{2}{|c|}{ Kode KPI }} & \multicolumn{7}{|c|}{ Perspektif Pelanggan } \\
\hline & & $\mathrm{C}-1$ & $\mathrm{C}-2$ & $\mathrm{C}-3$ & C-4 & C-5 & C-6 & $\mathrm{C}-7$ \\
\hline \multicolumn{2}{|c|}{ Performance } & 3.76 & 3.20 & 11 & 15.95 & 88.3 & 74.47 & 17.28 \\
\hline & 10 & 4.20 & 4.10 & 15.00 & 20.00 & 90.00 & 75.00 & 30.00 \\
\hline & 9 & 4.14 & 4.01 & 14.29 & 19.29 & 87.86 & 73.57 & 29.29 \\
\hline & 8 & 4.09 & 3.93 & 13.57 & 18.57 & 87.14 & 72.86 & 28.57 \\
\hline & 7 & 4.03 & 3.84 & 12.86 & 17.86 & 86.43 & 72.14 & 27.86 \\
\hline \multirow[t]{5}{*}{ Level } & 6 & 3.97 & 3.76 & 12.14 & 17.14 & 85.71 & 71.43 & 27.14 \\
\hline & 5 & 3.91 & 3.67 & 11.43 & 16.43 & 85.00 & 70.71 & 26.43 \\
\hline & 4 & 3.86 & 3.59 & 10.71 & 15.71 & 84.29 & 70.00 & 25.71 \\
\hline & 3 & 3.80 & 3.50 & 10.00 & 15.00 & 75.00 & 65.00 & 25.00 \\
\hline & 2 & 3.50 & 3.30 & 8.33 & 13.33 & 70.00 & 60.00 & 20.00 \\
\hline
\end{tabular}




\begin{tabular}{rccccccccc}
\hline $\begin{array}{c}\text { Kode } \\
\text { KPI }\end{array}$ & \multicolumn{7}{c}{ Perspektif Pelanggan } \\
\hline & C-1 & & C-1 & \multicolumn{5}{c}{ C-1 } & C-1 \\
\hline 1 & 3.20 & 3.10 & 6.67 & 11.67 & 65.00 & 55.00 & 15.00 \\
0 & 2.90 & 2.90 & 5.00 & 10.00 & 60.00 & 50.00 & 10.00 \\
\hline Level & 2.87 & 1.50 & 4.40 & 4.34 & 9.21 & 9.63 & 1.46 \\
Weight & 0.329 & 0.172 & 0.209 & 0.052 & 0.117 & 0.08 & 0.4 \\
Value & 0.94 & 0.26 & 0.92 & 0.23 & 1.08 & 0.77 & 0.58 \\
\hline
\end{tabular}

Bobot kepentingan dari perspektif pelanggan terbesar pada indeks persepsi mahasiswa terhadap pelayanan akademik (C 1) yaitu 0,329 (32,9\%) sedangkan bobot terendahnya KPI (C 7) presentase mahasiswa yang mendapatkan pelatihan softskills dan entrepreneurship.

Hasil pengukuran kinerja pada perspektif pelanggandiketahui bahwa ada 3 KPI yang masuk pada kategori buruk yaitu (KPI C1) indeks persepsi mahasiswa terhadap layanan akademik dengan nilai value 0,94 berada pada level 2,87 . Hasil pencapaian kinerja/ performance berada pada indeks 3,76 hampir mendekati target yang ditetapkan perguruan tinggi yaitu 3,80 .

Indeks persepsi terhadap layanan non akademik juga masih jauh dibawah target dengan capaian ratarata 3,20 dari target yang ditetapkan rata-rata 3,50 pada skala 1 s.d 5. Nilai kinerja untuk KPI presentase mahasiswa yang mendapatkan pelatihan softskills dan entrepreneurship termasuk kinerja ditolak (sangat buruk) berada pada level 1,46 sehingga membutuhkan perbaikan yang intensif dari perguruan tinggi dengan memperbanyak kegiatan kemahasiswaan serta upaya untuk menambah minat mahasiswa dalam mengikuti kegiatan pelatihan.

KPI Rasio peningkatan jumlah mahasiswa (C 3) berada pada level 4,4, sedangkan Presentase lulusan yang bekerja sesuai keilmuannya (C 4) pada level 4,33. Kinerja ketiga KPI ini diatas standar yang ada (cukup baik). Dua KPI yang nilai capaiannya mendekati nilai optimis (nilai maksimal) yaitu Presentase lulusan yang mendapatkan IPK $\geq 3.00$ (C 6) berada pada level 9,63 (memuaskan) dan KPI Presentase mahasiswa yang lulus dengan rata-rata masa pendidikan $\leq 4$ tahun (C 5) berada pada level 9,21 dengan nilai performance 88,3\%. Kinerja yang dihasilkan baik dari target yang ditetapkan sebesar $65 \%$.

Tabel 7. Skoring perspektif keuangan

\begin{tabular}{|c|c|c|c|c|}
\hline \multirow{2}{*}{ Kode KPI } & \multicolumn{4}{|c|}{ Perspektif Keuangan } \\
\hline & F-1 & F-2 & F-3 & F-4 \\
\hline Performance & 230.43 & 32.18 & 11.70 & 83.14 \\
\hline $\begin{array}{ll}\text { Level } & 10\end{array}$ & 350.00 & 20.00 & 15.00 & 50.00 \\
\hline
\end{tabular}

\begin{tabular}{rcccc}
\hline \multirow{2}{*}{ Kode KPI } & \multicolumn{4}{c}{ Perspektif Keuangan } \\
\cline { 2 - 5 } & F-1 & F-2 & F-3 & F-4 \\
\hline 9 & 342.86 & 21.43 & 14.29 & 54.29 \\
7 & 335.71 & 22.86 & 13.57 & 58.57 \\
6 & 328.57 & 24.29 & 12.86 & 62.86 \\
& 321.43 & 25.71 & 12.14 & 67.14 \\
5 & 314.29 & 27.14 & 11.43 & 71.43 \\
4 & 307.14 & 28.57 & 10.71 & 75.71 \\
3 & 300.00 & 30.00 & 10.00 & 80.00 \\
2 & 250.00 & 33.33 & 9.17 & 83.33 \\
1 & 200.00 & 36.67 & 8.33 & 86.67 \\
0 & 150.00 & 40.00 & 7.50 & 90.00 \\
Level & 1.61 & 2.35 & 5.38 & 2.06 \\
Weight & 0.191 & 0.163 & 0.271 & 0.375 \\
Value & 0.30751 & 0.38305 & 1.45798 & 0.7725 \\
\hline
\end{tabular}

Pada perspektif keuangan diperoleh hasil untuk KPI F 1 (current ratio)dengan nilai capaian 230,43\% dari target $300 \%$ yang dicanangkan perguruan tinggi, sehingga berada pada level 1,61 yang berarti indikator kinerja pada current ratio buruk/masih belum memenuhi target. Untuk indikator kinerja rasio Solvabilitas (F 2) dengan nilai capaian 32,18\% dari target $30 \%$ yang dicanangkan perguruan tinggi berda pada level 2,35. Makin kecil prosentase ratio ini berarti makin cepat perguruan tinggi menjadi insolvabel.

Untuk ROA (F 3) berada pada level 5,38 yang berarti indikator kinerja yang dicapai sedang atau di atas standar yang ada (cukup baik), sedangkan Presentase pembiayaan dari mahasiswa terhadap total anggaran Perguruan Tinggi berada pada level 2,06, dengan nilai capaian dibaah yang ditetapkan sbesar $80 \%$, pada nilai capaian kinerja berada pada $85 \%$, semakin kecil presentase pembiayaan dari mahasiswa terhadap total anggaran perguruan maka nilai kinerja semakin baik.

Tabel 8. Skoring perspektif bisnis internal

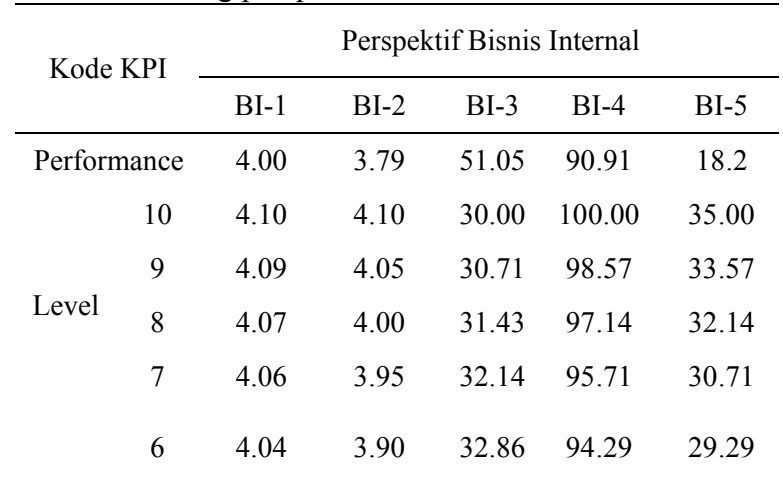




\begin{tabular}{rrrcccc}
\hline \multirow{2}{*}{ Kode KPI } & \multicolumn{5}{c}{ Perspektif Bisnis Internal } \\
\cline { 2 - 7 } & BI-1 & BI-2 & BI-3 & BI-4 & BI-5 \\
\hline & 4.03 & 3.85 & 33.57 & 92.86 & 27.86 \\
& 4 & 4.01 & 3.80 & 34.29 & 91.43 & 26.43 \\
& 3 & 4.00 & 3.75 & 35.00 & 90.00 & 25.00 \\
Level & 2 & 3.83 & 3.53 & 30.00 & 85.00 & 20.00 \\
& 1 & 3.67 & 3.32 & 35.00 & 80.00 & 15.00 \\
& 0 & 3.50 & 3.10 & 50.00 & 75.00 & 10.00 \\
\multicolumn{2}{c}{ Level } & 3.00 & 3.8 & 0 & 3.64 & 1.64 \\
\multicolumn{2}{c}{ Weight } & 0.287 & 0.45 & 0.121 & 0.055 & 0.086 \\
\multicolumn{2}{c}{ Value } & 0.86 & 1.71 & 0.00 & 0.20 & 0.14 \\
\hline
\end{tabular}

Pada perspektif bisnis internal hasil pengukuran kinerja diketahui bahwa ada 2 KPI yang masuk pada kategori sangat buruk yaitu rasio komposisi dosen per mahasiswa (BI 3) yang berada pada level 0, dan partisipasi mahasiswa dalam kegiatan (BI 5) pada level 1,64. Nilai performance pada rasio dosen terhadap mahasiswa mencapai 51,05 hal ini berarti setiap 1 dosen tetap mengampu 51 mahasiswa. Nilai rasio ini sangat jauh dari yang telah ditetapkan yaitu 1:30. Solusi yang harus dilakukan pihak perguruan tinggi adalah dengan menambah jumlah dosen tetap dari masing-masing program studi. Presentase mahasiswa dalam mengikuti kegiatan (BI 5 ) juga kurang dari target yang ditetapkan yaitu $25 \%$, karena nilai capaian yang mengikuti kegiatan hanya $18,20 \%$ dan masuk pada level 1,64. Kinerja pada KPI BI-5 termasuk buruk atau dengan kata lain di bawah ratarata.

Nilai performance dari KPI Indeks kepuasan karyawan (BI 1) berada pada indeks 3,00 dari skala likert 1 s.d 5, berada pada level 0 yang berarti capaian kinerja yang dihasilkan buruk, dengan kata lain karyawan belum mendapatkan kepuasan dalam bekerja. Untuk penilaian Indeks evaluasi kualitas pembelajaran dengan pengisian kuesioner online oleh mahasiswa dihasilkan nilai performance 3,79 yang berada pada level 3,8 yang berarti kinerja yang dicapai sedang atau di atas standar yang ada (cukup baik).

KPI Presentase sistem informasi manajemen yang berfungsi dengan baik (BI 4) berada pada level 3,64 . Walaupun capaian performance pada KPI ini melebihi target yang telah ditetapkan, akan tetapi pihak perguruan tinggi diharap mampu meningkatkan semua layanan sistem informasi manajemen agar dapat dimanfaatkan secara optimal.

Tabel
Tabel 9. Skoring perspektif pembelajaran dan pertumbuhan

\begin{tabular}{|c|c|c|c|c|c|c|c|c|}
\hline \multirow{2}{*}{\multicolumn{2}{|c|}{ Kode KPI }} & \multicolumn{7}{|c|}{ Perspektif Pembelajaran dan Pertumbuhan } \\
\hline & & LG1 & LG2 & LG3 & LG4 & LG5 & LG6 & LG7 \\
\hline \multicolumn{2}{|c|}{ Performance } & 88.24 & 0 & 0 & 41.18 & 47.06 & 100 & 45.45 \\
\hline \multirow{11}{*}{ Level } & 10 & 65.00 & 25.00 & 10.00 & 70.00 & 60.00 & 100 & 80 \\
\hline & 9 & 65.00 & 25.00 & 10.00 & 68.57 & 57.86 & 97.86 & 77.14 \\
\hline & 8 & 65.00 & 25.00 & 10.00 & 67.14 & 55.71 & 95.71 & 74.29 \\
\hline & 7 & 65.00 & 25.00 & 10.00 & 65.71 & 53.57 & 93.57 & 71.43 \\
\hline & 6 & 65.00 & 25.00 & 10.00 & 64.29 & 51.43 & 91.43 & 68.57 \\
\hline & 5 & 65.00 & 25.00 & 10.00 & 62.86 & 49.29 & 89.29 & 65.71 \\
\hline & 4 & 65.00 & 25.00 & 10.00 & 61.43 & 47.14 & 87.14 & 62.86 \\
\hline & 3 & 65.00 & 25.00 & 10.00 & 60.00 & 45.00 & 85.00 & 60.00 \\
\hline & 2 & 63.33 & 16.67 & 6.67 & 53.33 & 40.00 & 81.67 & 56.67 \\
\hline & 1 & 61.67 & 8.33 & 3.33 & 46.67 & 35.00 & 78.33 & 53.33 \\
\hline & 0 & 60.00 & 0.00 & 0.00 & 40.00 & 30.00 & 75.00 & 50.00 \\
\hline \multicolumn{2}{|c|}{ Level } & 10 & 0 & 0 & 0.18 & 3.96 & 10 & 0 \\
\hline \multicolumn{2}{|c|}{ Weight } & 0.274 & 0.229 & 0.196 & 0.079 & 0.104 & 0.069 & 0.049 \\
\hline \multicolumn{2}{|c|}{ Value } & 2.74 & 0.00 & 0.00 & 0.01 & 0.41 & 0.69 & 0.00 \\
\hline
\end{tabular}

Kinerja pada perspektif pembelajaran dan pertumbuhan dengan 7 KPI memperlihatkan yang kurang memuaskan karena 4 KPI berada pada level 0 . KPI Presentase dosen bergelar bergelar Doktor (LG 2) dan Presentase dosen bergelar bergelar Professor (LG 3) memiliki nilai performance 0, yang berarti perguruan tinggi belum memiliki dosen dengan kualifikasi doktor maupun professor. KPI Presentase dosen yang memiliki jabatan fungsional (LG 4) memiliki nilai performance $41,18 \%$ sehingga masih berada pada level 0.18. Presentase staf administrasi bergelar sarjana (LG 7) dengan nilai capaian $45,5 \%$ dari target $60 \%$, sehingga berada pada level 0 sedangkan nilai pesimis yang ditetapkan 50\%, capaian tersebut masih berada jauh dibawah target.

Dua KPI berada pada indikator sangat memuaskan yaitu KPI Presentase dosen bergelar master (LG 1) serta Presentase staf akademik/dosen dalam kegiatan pengabdian masyarakat (LG 6) yang berada pada level 10. KPI LG-1 telah mencapai kinerja memuaskan karena 88,23 \% dosen tetap bergelar master, dengan bobot global paling tinggi $27,8 \%$ diharapkan kinerja KPI LG 1 dapat meningkatkan nilai performansi pada perspektif pembelajaran dan pertumbuhan. KPI LG 6 berada pada level tertinggi 10 yang berarti memiliki kinerja sangat memuaskan.

Nilai indeks performansi total dari perspektif pelangan sebesar 4,26 yang didapatkan dari total value, maka dapat dilihat secara keseluruhan untuk perspektif pelanggan, kinerja yang dicapai sedang 
atau di atas standar yang ada (cukup baik).Nilai capaian kinerja perspektif keuangan perguruan tinggi didapatkan nilai indeks performansi sebesar 2,92 maka dapat dilihat secara keseluruhan indikator kinerja untuk perspektif keuangan yang dicapai masih dibawah standar (buruk).

Sedangkan nilai indeks performansi total dari perspektif bisnis internal sebesar 2,05 maka kinerja yang dihasilkan masih dibawah target standar (buruk).Nilai indeks performansi total dari perspektif pembelajaran dan pertumbuhan sebesar 3,89 kinerja perguruan tinggi untuk perspektif pembelajaran dan pertumbuhan kinerja standar (rata-rata).

Penilaian kinerja perguruan tinggi pada periode Desember tahun 2013 didapatkan indeks performansi total sebesar 3,37. Maka secara keseluruhan dapat dikatakan bahwa kinerja yang dihasilkan perguruan tinggi STIE YPPI Rembang standar (sesuaidengan target), walau beberapa KPI masih ada capaian kinerja yang dibawah target tetapi secara umum sudah sesuai target

\section{Kesimpulan}

Kombinasi Balanced Scorecar dan Objective Matrix (OMAX) dalam pengukuran kinerja pada perguruan tinggi untuk membangun sistem pengukuran kinerja menjadi terintegrasi dan komprehensif dimana dalam penentuan indeks penilaian kinerjanya mempertimbangkan seluruh perspektif Balanced Scorecard yang didukung dengan model penilaian OMAX, perguruan tinggi dapat memantau semua aspek kinerjanya dan segera melakukan tindakan perbaikan untuk membenahi kinerja perguruan tinggi yang pencapaiannya masih jauh di bawah target, dengan tetap selalu meningkatkan capaian kinerja secara keseluruhan.

Kombinasiini merupakan integrasi yang baik yaitu mampu memodifikasi dalam model hybrid dari penggunaan kartu skor Balanced Scorecard pada perguruan tinggi yang berubah menjadi bentuk Objective Matrix, yang tidak hanya memantau kinerja berdasarkan target akan tetapi juga menyajikan sasaran dalam jangka panjang, yang secara sinergis menghasilkan kecepatan dan kemudahan pemantauan untuk mengendalikan kinerja organisasi, karena pihak manajemen dalam mengelola kinerja dapat mempertimbangkan factor strategi dan risiko, dengan kombinasi tersebut perguruan tinggi dapat menggunakan seluruh potensi sumberdaya yang tersedia secara optimal untuk mencapai tujuan.

Selain itu kombinasi BSC dan OMAX dapat menghin dari penggunaan terlalu banyak karena berfokus pada 4 perspektif, dengan indicator kunci (KPI) kinerja yang jelas dan fleksibel, sehingga setiap sasaran kinerja dapat dipantau dan dikendalikan dengan perspektif Balanced Scorecard.
Pembobotan antar perspektif dan masing-masing KPI menggunakan metode AHP melalui pengisian kuisioner berbasis internet, dimana dapat dengan cepat diketahui indeks konsistensi responden dalam mengisi kuisioner. Selain itu dengan melibatkan unsure pimpinan dapat diketahui bobot yang menjadi prioritas dari masing-masing KPI secara objektif.

\section{Ucapan Terima Kasih}

Terima kasih diucapkan pada STIE YPPI Rembang yang telah membantu kelancaran penelitian ini.

\section{Daftar Pustaka}

Aljardali, H., Mazen K.M. and Tadjine, T.L., 2012. The implementation of the balanced scorecard in lebanese public higher education institutions, Proceding Social and Behavioral Sciences, 62, 98-108.

BAN PT, 2008. Buku II Standar Dan ProsedurAkreditasi Sarjana, BAN-PT, Jakarta.

Beard, D.F., 2009. Applications of the balanced scorecard in higher education. Journal of Education for Business, 275-282.

Bentes, A.V, Carneiro, J., Da Silva, J.F. and Kimura, H., 2012. Multidimensional assessment of organizational performance: Integrating BSC and AHP. Journal of Business Research, 65, 17901990.

Dania, W.A.P., Santoso, I., Rheysa, P.S., 2012. Analysis of Performance measurement using performance prism method. Jurnal Teknologi Pertanian, 13 (1), 67-77.

Elgazzar, S.H, Tipi, N.S., Hubbard, N.J., Leach, D.Z., 2012. Linking supply chain processes' performance to a company's financial strategic objectives. European Journal of Operational Research, 223, 276-289

Faridz, R., Burhan dan Wijayantie, E., 2011. Pengukuran dan analisis produktifitas produksi dengan metode objective matrix (OMAX) di PG. Krebet Baru Malang. Agrointek, 5 (11), 80-87.

Jaaskelainen, A., 2009. Identifying a suitable approach for measuring and managing public service productivity. Electronic Journal of Knowledge Management, 7, 447-458.

Lee, S.H., 2010. Using Fuzzy ahp to develop intellectual capital evaluation model for assessing their performance contribution in a university. Expert Systems with Applications, 37, 49414947.

Lee, A.H., Chen, W.C., dan Chang, C.J., 2008. A Fuzzy AHP and BSC approach for evaluating performance of IT Department in the manufacturing industry in Taiwan. Expert Systems with Applications, 34, 96-107. 
Pedrycz W and Song, M., 2014. A Granulation of linguistic information in AHP decisionmaking problems. Information Fusion, 17, 93-101.

Purnomo, A., 2011. Pedoman Pengukuran Kinerja Distribusi dengan Balanced Scorecard dan Objectives Matrix Di PT MQ Consumer Goods, Prosiding Seminar Nasional Industrial Services, Bandung, 11-12 Mei, 1-9.

Riggs, J.L., 1987. Production System: Planning, Analysis and Control, Formerly Oregon State of University.

Saaty, TL., 2000. How to make a decision: the analytic hierarchy process, European Journal of Operation Research, 48 (1), 9-26.

Sordo, C.D., Orelli, R.L., Padovani, E., and Gardini, S., 2012. Assessing Global Performance in Universities: An Application of Balanced Scorecard, Proceding Social and Behavioral Sciences, 46, 4793 - 4797.

Sulisworo, D., and Darmawati, D., 2011. Balance scorecard and objective matrix integration for performance targeting method of infocom business. Indian Journal Of Commerce \& Management Studies, II, 50-60.

Suliantoro, H. dan Intan, G.M., 2007. Perancangan Sistem pengukuran kinerja dengan metode performance prism, J@TI Undip, II (2), 49-64.

Torodovic, M., Jaksic, M.L. and Marinkovic, S., 2011. Sustainable technology management indicators: objectives matrix approach. African Journal of Business Management, 5 (28), 1138611398.

Wu, H.Y, Lin, Y.K., and Chang, C.H., 2011. Performance evaluation of extension education centers in universities base on the balanced scorecard. Journal Evaluation and Program Planning, 37-201.

Wu, H.Y., Chen, J.K., Chen, I.S., dan Zhuo, H.H., 2012. Ranking Universities based on performance evaluation by a hybrid MCDM model. Measurement, 45, 856-880. 